J. Clin. Chem. Clin. Biochem.

Vol. 14, 1976, pp. 79-81

\title{
The Problem of Peak Identification in Crossed Immunoelectrophoresis: A Modification of the Technique of Platt et al.
}

\author{
By F. Aguzzi, D. Caro', A. Tartara and Nicoletta Poggi \\ Ospedale di Broni e Stradella \\ Laboratorio di Analisi Chimico-Cliniche e Microbiologiche
}

(Eingegangen am 8. August/17. Oktober 1975)

Summary: After a brief review of the known techniques for the identification of crossed immunoelectrophoresis peaks, the authors claim that the technique of Platt et al ((1973), Clin. Chim. Acta 46, 419-429) is the most effective. This consists of blocking a protein in the first run, thereby causing the disappearance of the corresponding peak in the second dimension. The advantages of this technique with respect to the others are discussed.

\section{Das Problem der Peak-Identifizierung bei der Laurell-Elektrophorese: Eine Modifikation der Technik von Platt et al.}

Zusammenfassung: Nach einer kurzen Ubersicht der bekannten Methoden zur Identifizierung von Laurell-Elektrophorese-Peaks, halten die Verfasser die von Platt et al. ((1973), Clin. Chim. Acta 46, 419-429) vorgeschlagene Technik für die günstigste. Diese besteht in der Blockierung des Proteins in der ersten Electrophoresephase, womit der entsprechende Peak in der zweiten Electrophoresephase verschwindet. Die Vorteile dieser Methode gegenüber anderen werden besprochen.

\section{Introduction}

Identification of peaks is one of the most important problems (1) presented by crossed immunoelectrophoresis (2). For some antigens a specific staining is possible $(3,4,5)$ and if access to pure proteins is available, it is possible to use $K r \phi l l$ tandem-crossed immunoelectrophoresis (6). If specific antibodies are available there are greater possibilities for identification. These are based on the removal of a determined peak by means of the corresponding antiserum. This can be achieved by precipitation either before the first (2) or during the second electrophoretic run with the method suggested by Stephan (7), or with the conceptually similar method, using an intermediate gel $(8,9)$.

In both cases problems are causèd by the fact that most specific antisera contain human serum proteins, derived from the absorption procedure used during the preparation. These ballast proteins in the second run react with the whole antiserum causing a diffused inking of the background or a pattern similar to that of $K r \phi l l$ immuno-line-electrophoresis (10). In particular, with the intermediate gel method, the addition of these to the antigens of the serum under examination often causes the appearance of new peaks and/or the disappearance of others through alterations of the antigen-antibody ratio; this creates a picture which is rather different from the original. In 1973 Platt et al. (11) published a technique in which a part of the first dimension gel contains monospecific antiserum. This results in the precipitation of the corresponding antigen in the form of a Laurell rocket and the reduction or disappearance of the second dimension peak.

\section{Material and methods}

In our laboratory we have developed, for clinical use, a microtechnique of the crossed immunoelectrophoresis. By using fixed quantities of human antiserum (Behringwerke, $50 \mu \mathrm{l}$ ) and antigen (total proteins $=7.5 \mu \mathrm{g})(12)$, the cost is decreased and the number of peaks is reduced, while the more important peaks remain visible. For the identification of the peaks we had two main problems:

1) the relatively constant peaks of the normal pattern were resolved by specific staining and by the intermediate-gel technique;

2) more difficult was the problem of recognizing the peaks of pathological patterns, in themselves strongly deviant from the normal pattern, and therefore more subject to modifications caused by adding the monospecific antiserum residual proteins. In principle we found that the technique proposed by Platt et al. was more practical, but we had to introduce some modifications 

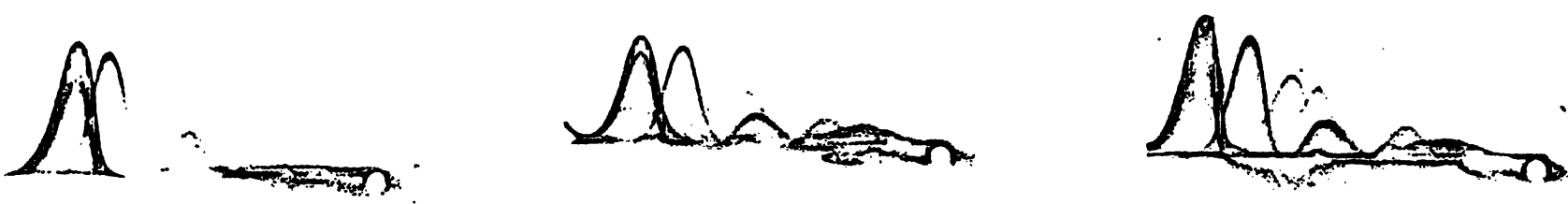

Fig. 1. Example of identification used to ascertain the nature of doubtful peak (third from the left) in a pathological crossed immunoelectrophoresis (first slide). The differential possibilities include $\alpha_{1}$-glycoprotein, Gc-globulin, haptoglobin 1-1 inter $\alpha$ trypsin-inhibitor. In the second slide the peak is identified as $\alpha_{1 X}$-glycoprotein while in the third experiment shows haptoglobin.

to adapt it for clinical use. In fact Platt removed a strip $(1 \mathrm{~cm}$ wide; $2.5 \mathrm{~cm}$ long) from the first-dimension agarose and replaced it with agarose containing $50 \mu$ of monospecific antiserum.

As the first run was normally conducted with many samples side by side on a single slide, technically it was not easy to remove strips of equal width; and it was even more difficult to fill each resultant trough with agarose containing different antibodies, except for the two extremes.

Even if it were possible, there would be diffusion problems. On the other hand, for clinical use, it is useful to perform contemporaneously a battery of identifications; for example if the identification of a peak between $\alpha_{1}$ and $\alpha_{2}$ is doubtful (fig. 1). We resolved the problem by constructing a rectangular mould with rounded extremities $(23 \mathrm{~mm} \times 5.5 \mathrm{~mm})$ by shaping a metal tube to the above dimensions (We have verified that this width is sufficient to obtain the blockage of the antigen using a well of $2.5 \mathrm{~mm}$ ). This easily allows the construction of a trough (volume approximately $150 \mathrm{~mm}^{3}$ ) in the agarose of the first run in any position on the slide (fig. 2). These reduced dimensions permit considerable saving of antiserum when compared to the original technique. The quantity of antiserum required can be calculated by the titer of the antibody and by the presumable quantity of antigen contained in the mixture.

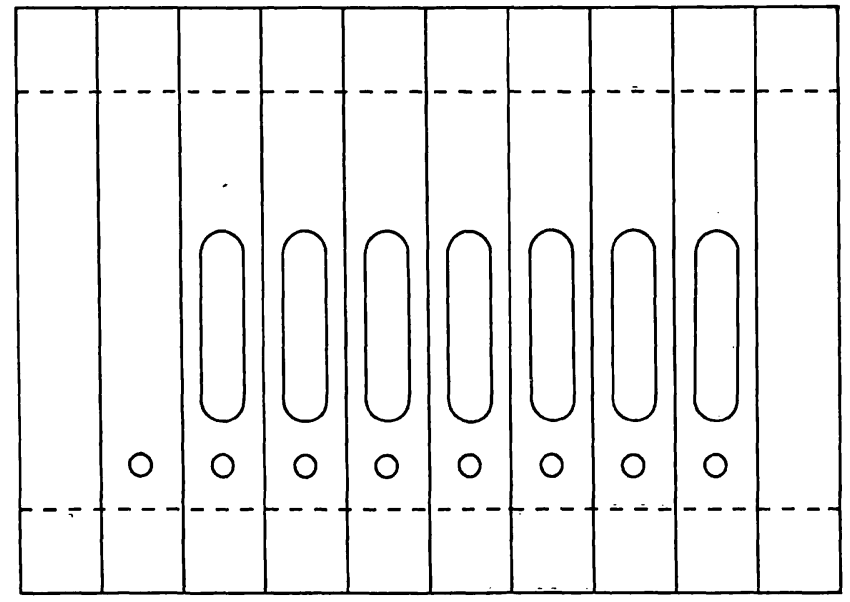

Fig. 2. Diagram showing the first-dimension plate as it is used to carry out a battery of identifications. The control run shows only the well, while for the others the position of the trough to be filled with the agarosegel-antiserum is indicated.

\section{Results and Discussion}

Table 1 shows the volume of specific antiserum required to eliminate the corresponding peak and to give a small first dimensional cone in normal cases, whose sera are so diluted that in the $5 \mu \mathrm{l}$ applied there is $7.5 \mu \mathrm{g}$ of total proteins. Normally the trough is situated 4-6 $\mathrm{mm}$ from the well in the direction of the anode; however, in the case of antisera particularly rich in human proteins it can be closer to the anode, in practice a few mm towards the cathode with respect to the minimal electrophoretic mobility of the antigen to be investigated. In figure 3 examples of identifications relative to haptoglobin, $C_{3}, \alpha_{1}$-antitrypsin, $\alpha_{2}$-macroglobulin, transferrin are given. The fundamental advantages of this experimental technique are its easy adaptability to clinical use, low cost, but above all the facility of interpretation.

In fact the ballast proteins of antiserum depart from a more anodic position, which permits the elimination of the summation with those of the sample.

Tab. 1. Quantity of specific antiserum required for the identification of some proteins.

\begin{tabular}{|c|c|c|c|}
\hline Protein & $\begin{array}{l}\text { Monospecific } \\
\text { antiserum }\end{array}$ & $\begin{array}{l}\text { Quantity } \\
\text { of } \\
\text { anti- } \\
\text { serum } \\
{[\mu l]} \\
\text { in trough }\end{array}$ & $\begin{array}{l}\text { Quantity } \\
\text { of } \\
\text { añti- } \\
\text { serum } \\
{[\mu l]} \\
\text { in } 100 \mathrm{ml} \\
\text { agarosegel }\end{array}$ \\
\hline $\begin{array}{l}\alpha_{1} \text {-antitrypsin } \\
\alpha_{1} \text {-glycoprotein } \\
\text { Inter- } \alpha \text {-trypsin-inhibitor } \\
\alpha_{1} \text {-acid glycoprotein } \\
\text { Gc-globulin } \\
\text { Ceruloplasmin } \\
\alpha_{2} \text { HS-gly coprotein } \\
\alpha_{2} \text {-macroglobulin } \\
\text { Haptoglobin } \\
\text { Hemopexin } \\
\text { Transferrin } \\
\beta_{1} C / \beta_{1} A\end{array}$ & $\begin{array}{l}\text { Behringwerke } \\
\text { Behringwerke } \\
\text { Behringwerke } \\
\text { Behringwerke } \\
\text { Behringwerke } \\
\text { Melloy } \\
\text { Behringwerke } \\
\text { Melloy } \\
\text { Behringwerke } \\
\text { Melloy } \\
\text { Behringwerke } \\
\text { Behringwerke }\end{array}$ & $\begin{array}{l}3.0 \\
1.2 \\
1.2 \\
3.0 \\
1.2 \\
1.0 \\
1.2 \\
1.8 \\
4.3 \\
2.4 \\
1.8 \\
1.2\end{array}$ & $\begin{array}{r}2000 \\
800 \\
800 \\
2000 \\
800 \\
640 \\
800 \\
1200 \\
2800 . \\
1600 \\
1200 \\
800\end{array}$ \\
\hline
\end{tabular}




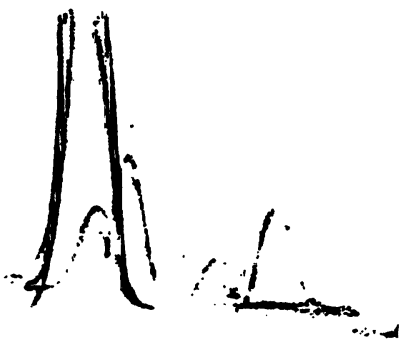

Control sample

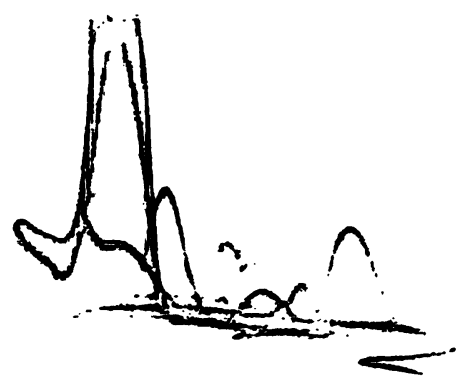

Haptoglobin

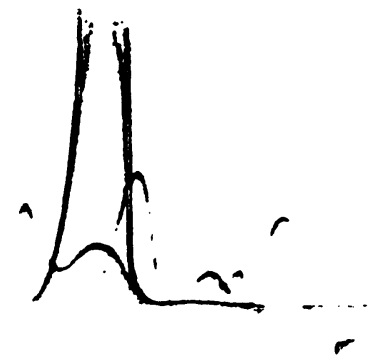

Complement $\mathrm{C3}$

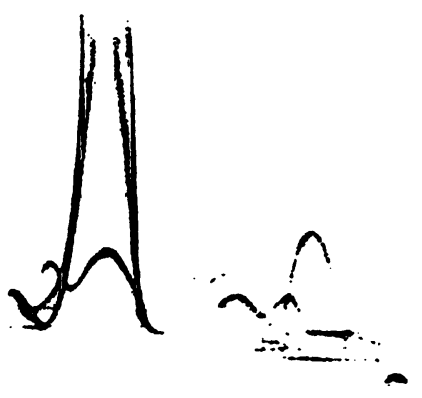

$\alpha_{1}$-Antitrypsin

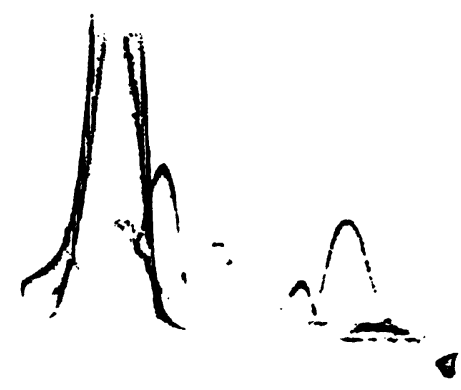

$\alpha_{2}$-Macroglobulin

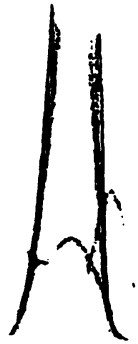

Transferrin

Fig. 3. Example of identification of several peaks (repere $=$ control sample; $\mathrm{Hp}=$ haptoglobin; $\alpha_{1}-\mathrm{Atr}=\alpha_{1}-$ antitrypsin; $\alpha_{2}-\mathrm{M}=\alpha_{2}-$ macroglobulin; $\operatorname{Tr} f=$ transferrin) in a normal serum. In every slide the disappearance of the peak corresponding to the investigated protein is seen.

The only interference is limited to the presence of irrelevant horizontal lines of precipitation close to the baseline or in some cases to the appearance of a double peak (as in Kr $\phi l l ' s$ tandem-crossed-immunoelectrophoresis) in the albumin zone, as can be seen in fig. 3. In each case it always very clear which peak should be eliminated.

\section{Referencès}

1. Weeke, B. (1970), Scand. J. Clin. Lab. Invest, 25, 269275.

2. Laurell, C. B. (1965), Anal. Biochem., 10, 358-361.

3. Uriel, J. (1964), in Immunoelectrophoretic Analysis, (Grábar, P. \& Burstin, P. eds.) pp. 30-57, Elsevier, Amsterdam.

4. Uriel, J. (1971), in: Methods in Immunology and Immunochemistry (Williams, C. A. \& Chase, M. W. eds.) vol III, pp. 294-321, Academic Press, New York and London:

5. Schen, R. J. \& Rabinowits, M. (1966), Clin. Chim. Acta, $13,537$.

6. Ku $\phi 11$, J. (1973), in: A Manual of Quantitative Immunoelectrophoresis (Axelsen, N., Kr $\phi 11$, H. \& Weeke, J. B. eds.) pp. 57-59, Universitetsforlaget, Oslo.
7. Stephan, W. \& Frahm, U. (1970), this j. 8, 391-393.

8. Axelsen, N. H. \& Svendsen, P. J. (1971), Protides Biol. Fluids, Proc. Colloq., 19, 561-564.

9. Svendsen, P. J. \& Axelsen, N. H. (1972), J. Immunol. Methods, 1, 169-176.

10. Krф11, J. (1973), Crossed-line Immunoelectrophoresis (Axelsen, N. H., Krфll, J. \& Weeke, B. eds.) in: A Manual of Quantitative Immunoelectrophoresis, Universitetsvorlaget, Oslo.

11. Platt, H. S., Sewell, B. M., Feldman, T. \& Souhami, R. L., (1973), Clin. Chim. Acta, 46, 419-429.

12. Aguzzi, F., Tartara, A., Carò, D., Poggi, N. \& Dammacco F. (1975), Boll. Ist. Sieroter. Milan., 54, 415-422. 
